\title{
GLACIAL SCULPTURE IN WESTERN NEW YORK*
}

BY GROVE KARL GILBERT

(Presented before the Society December 30, 1898)

\section{CONTENTS}

Introduction $\ldots \ldots \ldots \ldots \ldots \ldots \ldots \ldots \ldots \ldots \ldots \ldots \ldots \ldots \ldots \ldots \ldots \ldots$

Sculpture of the Niagara limestone $\ldots \ldots \ldots \ldots \ldots \ldots \ldots \ldots \ldots \ldots \ldots \ldots \ldots \ldots \ldots$

Sculpture of the Clinton and Medina ledges. . . . . . . . . . . . . . . 125

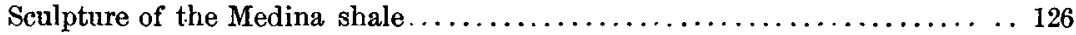

Summary ................................... 129

\section{INTRODUCTION}

The question whether the Pleistocene ice-sheets accomplished a large amount of rock erosion has been a fruitful subject of discussion. The most diverse views have been expressed, and there are probably still some geologists who think that the ice executed only a slight superficial scraping and polishing, as well as others who ascribe to it works of such magnitude as the excavation of the basins of the Laurentian lakes. The most important recent contribution is by Goodchild, who shows that the topography of a large district in Scotland, a district largely occupied by sandstones, breccias, and other resistant rocks, was remodeled by Pleistocene ice. Its topography is rugged in detail, comprising many hills and valleys, and these features, instead of conforming in trend to the strike of the rocks, conform to the direction of ice motion, which makes wide angles with the strike. $\dagger$

In line with his conclusions are the phenomena of the Finger Lakes region in western New York. Many of the more striking features of that region have been ascribed by various writers to ice sculpture, + and $m y$ own observation, which has been somewhat extensive, supports that conclusion. It appears to me that the peculiar topographic facies of the great body of Devonian shales underlying that district owes more to. ice work than to antecedent water work; and that the face of the country is

* The observations set forth in this and the two following papers were made by the author as a member of the U. S. Geological Survey, and are here published with permission of the Director of the survey.

$\dagger$ J. G. Goodchild : Glacialist Magazine, vol. iv, 1896, pp. 1-7.

ISee Bull. Geol. Soc. Am., vol. 5, pp. 339-356. 
essentially a moutonnée surface, the bosses of which are measured horizontally by miles and vertically by hundreds of feet.

While the glacial sculpture of this district is probably as profound as in the district described by Goodchild, the indicated work is less, because the softer rock offered less resistance, and in northern New York, where the rocks are comparable in hardness with those of the Scottish district, the ice seems to have accomplished comparatively little. Sandstones and limestones are not there so disposed as to afford good comparative data; but in a tract of crystalline schists lying northeast of Carthage, and nearly bare of drift, the sculpture features are very different from those depicted by Goodchild. The principal structure of the schist is vertical, and its trend makes wide angles with the direction of ice motion. The ridges, which are at most only a few scores of feet in height, conform in trend with the strike of the foliation, and have been but slightly remodeled by sculpture on lines of ice motion. The bosses of the moutonnée pattern are measured by yards or rods.

While these observations tell of ice action much less energetic than in Goodchild's Scottish field, they do not conflict with his conclusions, but merely show that local conditions were different. Whatever the general potency of glacial ice, a wide variation of local power should be assumed, and the extent to which ice is responsible for the topography of a district is ordinarily a problem to be solved only through the study of local phenomena. The question of the origin of the basins of the Iaurentian lakes and of the share of work borne by ice is, in my judgment, by no means insoluble, but will yield eventually to the careful accumulation and scrutiny of available facts. The present paper, while avoiding the general discussion, presents a body of facts which it is hoped may contribute to the observational basis of the ultimate discussion.

During the summer of 1898 my field work as a member of the United States Geological Survey consisted in the detailed mapping of a district along the shore of lake Ontario in New York extending from the Niagara river eastward about 30 miles to the eastern boundary of Niagara county. Reconnaissances had previously covered Orleans and Monroe counties, so that some of the conclusions reached in the district of detailed work could be extended with fair approximation from the Niagara river to the Genesee.

Observations on glacial sculpture pertained to the Niagara limestone, the ledges at the base of the Niagara escarpment, and the Medina shale.

\section{Sculpture of the Niagara Limestone}

In western New York the strata incline gently toward the south, the rate varying usually between 25 and 50 feet to the mile, but the general 
surface slope is toward the north. It results that the various formations reach the surface in parallel belts running east and west. Some of the harder rocks find topographic expression in lines of cliff facing northward, and this is especially true of the Corniferous limestone and Niagara limestone, each of which is a resistant sheet interleaved between thick formations of more yielding material. The Niagara cliff is the more northerly and runs parallel to the lake at a distance of about 10 miles.

The Niagara limestone is here 190 feet thick. Only a small portion is exposed in vertical section along the cliff; the remainder is beveled

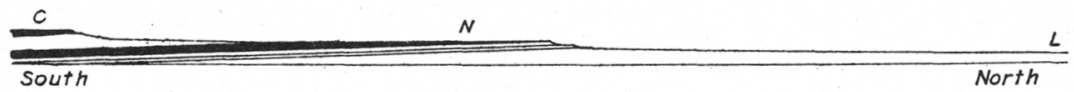

Figure 1.--Profile and Section in western New York from the Corniferous Terrace to Lake Ontario.

Vertical scale five times the horizointal. Distance represented, 25 miles. Baseline at sealevel. $C$, Corniferous limestone. $N$, Niagara limestone. $L$, shore of lake Ontario.

off so as to present an inclined plain 8 or 10 miles broad. This plain descends southward, the southern boundary of the outcrop being 50 to 75 feet lower than the northern. The configuration of the rock surface is in general concealed by drift, but a few prominences are exposed. The outlines of these trend in various directions and do not conform to the direction of ice motion.

MIDDLEPORT

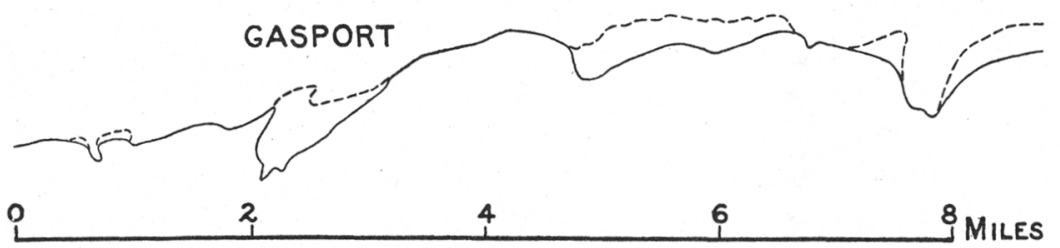

Figure 2.-Map of Niagara Limestone and Escarpment.

The locality is near Gasport and Middleport, New York. The full line shows the boundary between the Niagara limestone (south) and the Niagara shale (north). The broken line shows the position of the Niagara escarpment where not coincident with the boundary of the limestone.

The northern boundary of the formation and the associated cliff were examined in detail through a space of 30 miles. For the greater part of this distance the rock is exposed to view in the crest of the cliff, but elsewhere it is more or less buried, and observation was less satisfactory. A notable, and to me surprising, feature is the absence of the limestone from the cliff through considerable spaces. From Middleport westward for a distance of 7 miles only about one-half of the cliff is capped by limestone, the remainder exhibiting the underlying shale. The accompanying map, figure 2 , shows the relation of the limestone to the cliff in this 
region. When not coincident with the cliff, the boundary of the limestone could not be mapped in detail, as it is largely covered by the drift,

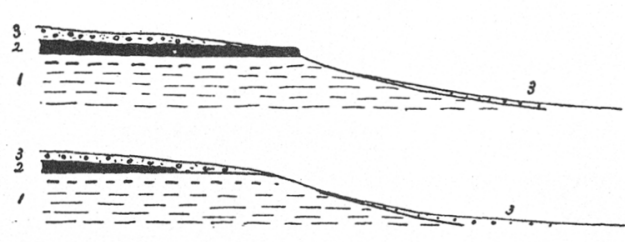

Figure 3.-Typical Profiles of the Niagara Escarpment.

The profiles are drawn with and without the Niagara limestone. 1, Niagara shale. 2, Niagara limestone. 3, Drift.

the preglacial topography or had been created by ice erosion, and this question seems to be answered by the phenomena already described. The occasional absence of the limestone from the crest of the escarpment suggests that the action of the ice may have tended even to obliterate the cliff; and certainly if it had created the cliff by rapid erosion of the shale where unprotected by the limestone, we could not expect it to reverse the process and uncover the shale by carrying away the protecting armor. Moreover, the southward slope of the plain on the back of the limestone-a slope in the ciirection of the dip, but opposed to the general descent of the region-is characteristic of subaerial and not glacial erosion, and the failure of minor ridges of that surface to conform in trend to the direction of ice motion indicates that the surface received comparatively little modification from the ice. All the more general features of the limestone belt thus seem to be preglacial.

From the Niagara river eastward to Lockport, a distance of nearly 20 miles, the edge of the limestone is almost continuously exposed to view, and with slight exception it coincides with the escarpment. The general course is east and west, but the outline is diversified by salients and reentrants, so that the cliff may be divided into two sets of courses, the one trending south of west and the other south of east. The general direction of ice motion in the region was toward the southwest, and it was thus diversely related to the two cliff trends. Where the cliff face trends toward the southwest, or approximately in the direction of ice motion, its contours are simple. Where it trends toward the southeast, so as to make a wide angle with the direction of ice motion, its contours are deeply inflected or serrated, the axes of serrations being parallel to the glacial striæ. In other words, the portions of cliff whose faces were directly opposed to the ice advance are characterized by furrows, and the portions met by the ice at a small angle are free from furrows. The furrows have smooth sides and bottoms, the latter rising slowly to the level 
of the plain, and their configuration is in all respects characteristic of glacial erosion. They range in depth from 10 to 30 feet, are usually several hundred feet broad, and the longest probably extends more than a half mile into the plain. The diagram in figure 4 shows the general character of the rock contours, but without representing any individual contour at equal height above the sea. The equivalent topographic outline is less sinuous, because the rock furrows are largely filled by drift.

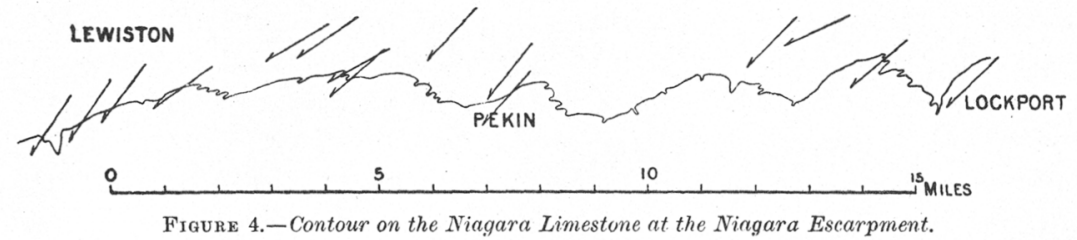

The escarpment faces north. Arlows show observed directions of glacial striæ.

The configuration of the cliff seems to show that in the regions where the trend is southwest all minor salients have been pared away by the ice, and that where the trend is southeast minor irregularities of the face have been exaggerated and small reentrants drawn into furrows; but the principal salients and reentrants of the topography are preserved, and ice modification is limited to minor details of form.

Considering this evidence of cliff sculpture, in connection with the removal of the limestone in the Middleport region and the non-glacial shapes of the rock ridges of the upper plain, it would appear that the ice-sheet concentrated its work, so far as the Niagara limestone is concerned, on the crest of the escarpment, and that even there its results were of secondary.rather than primary importance. Probably the limestone at its escarpment lost on the average only 10 to 20 feet of thickness, and from the broad belt of outcrop the general loss may have been as small as 5 feet.

\section{Sculpture of the Clinton and Medina Ledges}

Beneath the Niagara limestone are 80 feet of shale belonging to the Niagara formation ; then 25 feet of limestone (Clinton), and then a great body of shales (Medina and Hudson River), containing a few sandstone lenses near the top. The Clinton limestone and the sandstone ledges are strong beds, but the remainder of the section consists of weak shale, opposing little resistance to erosion. The Clinton limestone is continuous and uniform, the sąndstones discontinuous. The sandstones lie at various depths below the limestone, ranging from 40 to 100 feet. The heaviest sandstone is 20 feet thick at Lewiston, diminishes eastward in a few miles to 4 feet, then thickens to 14 feet, and finally disappears near 
Pekin. After an interval of 4 miles another lens appears at about the same horizon and continues eastward for 20 or more miles, being accompanied near Lockport by two other lenses, one abave and the other below.

In preglacial time the topography of the country was presumptively of subaerial type. As the Niagara escarpment was then in existence, the land was not at baselevel, and the general features of a larger district show that the slope of the country was then, as now, toward the north. We may assume, therefore, that the land north of the escarpment was traversed by north-flowing streams and was characterized by a system of parallel valleys and interstream ridges. In passing each stream valley the outcrops of the ledges were deflected southward, and in passing the intervening ridges northward, so that the outline of each outcrop comprised a series of reentrants and salients. This scalloped pattern is not now found, and its absence is to be ascribed to ice sculpture. Each ledge has lost its projecting capes, and may have lost a large

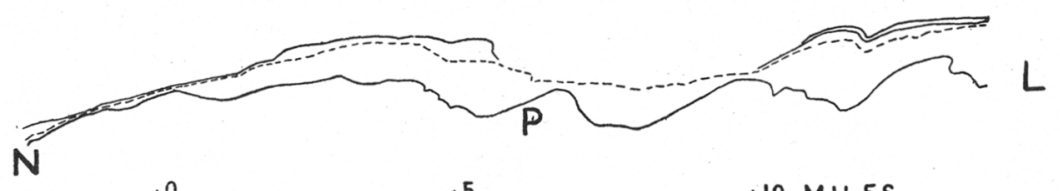

0

FigURE 5. - Plan of the northern Boundaries of resistant Ledges.

The lower (south) full line is the boundary of the Niagara limestone. The broken line is the boundary of the Clinton limestone. The upper full lines are boundaries of sandstone lenses of the Medina formation. $N$, portion of Niagara river. $P$, Pekin. $L$, Lockport.

territory in addition. At two points near Pekin, where the Clinton limestone has no support from underlying sandstone, it has been eaten back to the very base of the Niagara cliff, and the same is true for a space of several miles near Lewiston, although there its resistance was reenforced by that of a strong sandstone ledge. On the Canadian side of the Niagara river not only are the limestone and sandstone worn back to the Niagara escarpment, but the underlying shale has been removed to a depth of about 40 feet, so that the whole escarpment has a height of 250 feet, with the outcrop of the Clinton limestone midway on the slope. No data have been found on which to base an estimate of the extent to which these ledges have been eroded, but it seems clear that the belt of removal was much broader than in the case of the Niagara limestone, so that the Niagara escarpment was rendered more prominent than formerly by the erosion of material at its base.

\section{Sculpture of the Medina Shale}

The main body of the Medina formation below the sandstone ledges consists of red shale and has a thickness of several hundred feet. This 
underlies a plain about 7 miles broad, sloping northward from the foot of the escarpment to the shore of lake Ontario and descending in that distance 100 to 175 feet. If this plain were featureless, each traversing stream would follow the shortest path to the lake and its course would be normal to the lake shore. In fact, however, only a few streams take this direct route, and the majority are deflected toward the east, running northeastward instead of northward. On the accompanying map it will be noted that Johnson creek runs northeastward for 15 miles, Oak Orchard

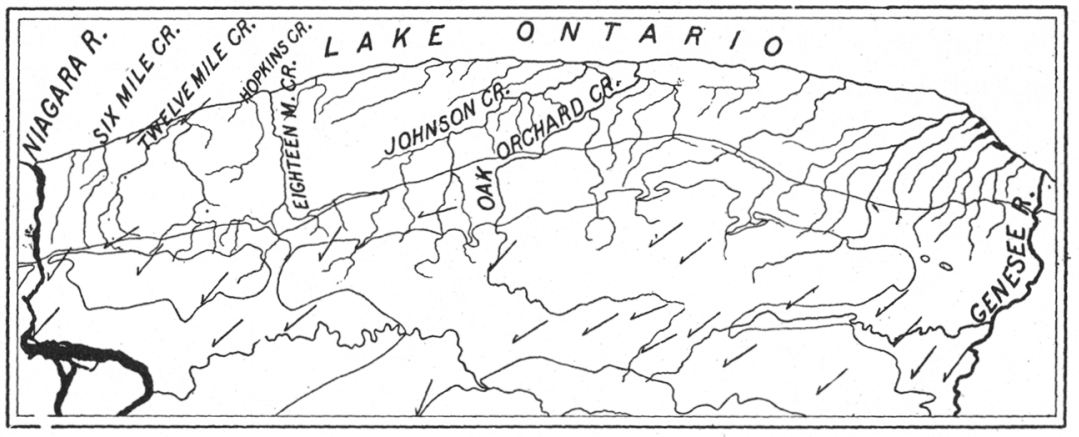

Figure 6.-Drainage Map in western New York.

The area represented measures 75 by 31 miles. The smooth lines are contours at 400,600 , and 800 feet above tide. The southern boundary of the Medina shale lies between the 400-foot and 600-foot contours. Arrows show the direction of ice motion as recorded by striæ and drumlins.

for nearly the same distance, and most of the minor streams reaching the lake between Johnson creek and Eighteenmile creek have northeasterly courses. Other streams, like Sixmile and Hopkins creeks and the west branch of Twelvemile, are made up of reaches alternating northward and northeastward in direction, reminding one of the drainage lines among folded rocks which alternately follow and cross the strike. 'The east branch of Eighteenmile creek has for 7 miles a southwest course parallel to the northeasterly courses of other creeks.

Some of these peculiarities were noted by Hall, who suggested control by a system of rock fissures, * but this explanation is unsatisfactory, as the general trend of joints in the district is due east and west.

In these days of accepted glacial theory, when the idea of topographic modification by ice is familiar to all, glacial action readily suggests itself in explanation of anomalies of drainage, and the working hypothesis with which I entered the field was that of control by ridges of drift. It was already known that a lobe or deep current of the ice-sheet followed the Ontario basin from east to west, spreading southward in such a way 
as to produce striæ gradually curving from west to south, and the peculiarities of drainage under consideration were seen to fall into this general scheme of trends.

Only a few days of close observation were necessary to show that the drift-ridge hypothesis was inadequate, and it was finally abandoned for all the Medina plain except a tract in Monroe county near the Genesee river. The principal facts leading to its abandonment are connected with the depth of the drift. If the creeks were guided by ridges of drift the general depth of drift should be greater in the interstream tracts than under the stream valleys, but the reverse of this obtains through nearly the whole district of peculiar drainage. Along the creeks running ning northeast the drift mantle is relatively thick; between them it is relatively thin.

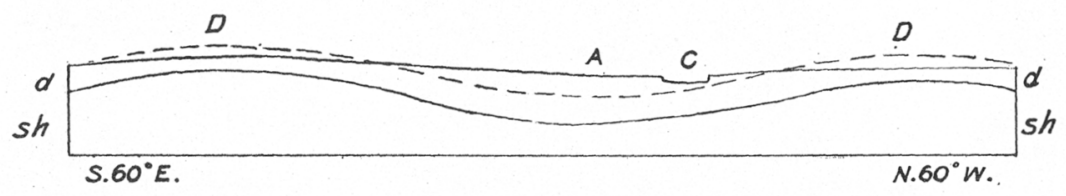

FIGURE 7.-Diagrammatic Section of glacial Furrow and Ridges.

$s h$, shale of the Medina formation. $d d$, drift. $D D$, region of sub-lacustrine degradation. $A$, region of sub-lacustrine aggradation. $C$, creek valley. The dotted line shows original profile of glacial drift.

The greater part of the surface was flooded by the glacial lake Iroquois, and that lake had an important influence on the topography, not merely silting up hollows with its sediments, but washing till from the hills and ridges and reducing the whole surface to a gently undulating plain. This plain is so even that the faint ridges by which the drainage is actually controlled are hardly discernible by the eye. Where the drift was eroded by the agitation of the lake water only its finer material was removed, the boulders being left, and the regions of greatest lacustrine degradation are represented at the present time by tracts of stony land, whose unfortunate owners, after utilizing the boulders as far as possible in the making of fences, construct great cairns from the surplus without seeming to exhaust the supply. This accumulation of residuary boulders is distinguished from bouldery till by the fact that it is only superficial. At a depth of 2 or 3 feet the evidence of concentration ceases, and the till below is but moderately stony. In a few localities the layer of boulders rests directly on the red shale, and the remnant of finer drift is too small for.profitable culture. In belts of lacustrine aggradation, on the other hand, the soil is stoneless clay or sand, or sometimes gravel, and the drift is deeper, often so deep that the farmer's well does not reach its base. 
From these facts it appears that if the drift were wholly removed and the rock surface bared the topography would comprise a series of ridges and troughs running parallel to the trend of the northeasterly streams. The details of rock configuration conform to the direction of ice motion, and are evidently products of glacial erosion.

The depth of the furrows is not definitely known, but some of them exceed 40 feet. Measurement was largely dependent on the facilities afforded by surface wells, and these do not completely traverse the drift in the deeper furrows. The significant fact is that throughout a considerable area the preglacial topography, presumably including a system of shallow valleys descending northward, was obliterated, and a radically different system of valleys was wrought. This could hardly have been accomplished without a general reduction of the surface to the extent of 40 or 50 feet, and the amount may have been considerably greater. The amount was surely greater in the vicinity of the Niagara river, where erosion, as already mentioned, not only carried the outcrop of the chief sandstone ledge back to the line of the Niagara escarpment, but removed so much of the underlying shale that the sandstone outcrop now contours the face of the escarpment for some distance above its base.

The failure of the glacial furrows to control the courses of Eighteenmile creek and Niagara river is due to local conditions. At each of these points the lowering of glacial lakes to the plane of lake Iroquois was accompanied by a stupendous torrent pouring over the Niagara escarpment,* and the detritus thus borne northward helped to silt up the glacial furrows of the plain. The subsequent lake action completed the work of gradation, so that when Iroquois was drained away these two streams found lines of continuous descent before them and chose direct courses to lake Ontario.

\section{Summary}

The ice left the broad plateau of firm Niagara limestone with little modification. The cliff at its northern edge was somewhat worn, but its position not materially changed. The resistant ledges north of the Niagara limestone were worn back so far as to lose the contours typical of subaerial erosion. The topography of the Medina shale was reconstructed, its system of stream valleys and interstream ridges being replaced by glacial fluting on a large scale. While the Niagara escarpment antedates the period of glacial sculpture, ice erosion rendered it

* Bull. Geol. Soc. Am., vol. 8, p. 286. 
130 G. K. GILBERT-GLACIAL SCULPTURE IN WESTERN NEW YORK

more prominent by excavation along its base and by the general degradation of the lowland it overlooks.

The district exhibits a marked contrast between the extent of erosion from a broad mass of limestone on the one hand and a broad mass of shale on the other, the ratio being, roughly, as 1 to 10 or 1 to 20 . 